\title{
COMMENTS
}

\section{Marijuana Hot Spots: Infrared Imaging and the Fourth Amendment}

\author{
Michael L. Huskins $\dagger$
}

Over fifty years ago, Justice Murphy warned of the threat to the Fourth Amendment posed by "new methods of photography that penetrate walls or overcome distances." Dissenting from a majority decision permitting the warrantless use of a "detectaphone" (a device that allows conversations in an adjoining room to be heard), Justice Murphy recognized the Fourth Amendment concerns raised by the application of technology to police surveillance work. ${ }^{2}$ He correctly identified the difficulty of protecting " $t]$ he right of the people to be secure in their persons, houses, papers, and effects, against unreasonable searches and seizures" when technology substantially increases the ability of the police to peer into an individual's life. ${ }^{3}$

A recent technological advancement, infrared imaging, raises similar Fourth Amendment concerns. The police have used infrared imagers-devices that detect infrared radiation and translate it into visible images-to identify indoor marijuanagrowing operations. Because indoor marijuana cultivation requires the use of high-power electric lamps that produce large amounts of infrared radiation, police can infer that structures emitting unusually large amounts of infrared radiation conceal marijuana-growing operations. In a typical case, after receiving

$\dagger$ A.B. 1992, Princeton University; J.D. Candidate 1996, The University of Chicago.

1 Goldman $v$ United States, 316 US 129, 139 (1942) (Murphy dissenting).

2 Id at 136-42.

${ }^{3}$ See id at 139-40, citing US Const, Amend IV. 
information that a house may conceal a marijuana-growing operation, the police might question the neighbors, visually inspect the premises from outside the property's perimeter, or obtain past electricity bills for the house. ${ }^{4}$ The police may also use infrared imaging to substantiate their suspicions that heat lamps are being used to grow marijuana.

Before they can enter the structure to search for marijuana, the police must obtain a warrant from a neutral and detached magistrate. ${ }^{5}$ The magistrate may issue a warrant only if he decides that the evidence presented by the police, including the results of infrared imaging, establishes probable cause to issue a search warrant for the structure. ${ }^{6}$ If a warrant is issued and executed, and the search leads to an arrest, the defendant will likely move to suppress the evidence gathered by the police on the ground that the warrantless infrared imaging violated the Fourth Amendment's prohibition against unreasonable searches.

Most courts have denied these motions, generally ruling that infrared imaging does not constitute a search for purposes of the Fourth Amendment. ${ }^{7}$ Such a ruling ends the constitutional inquiry because law enforcement practices that are neither "searches" nor "seizures" are not subject to Fourth Amendment scrutiny. ${ }^{8}$ Thus, this characterization essentially allows the police to use infrared imaging in any manner they desire, free from judicial oversight.

To reach the conclusion that infrared imaging is not a search, courts have followed several different lines of reasoning, none of which is entirely satisfactory in light of the technological capabilities of infrared imaging. Moreover, other courts have reached the opposite conclusion, holding that infrared imaging does constitute a search and, as such, is subject to the Fourth Amendment's warrant requirement. ${ }^{9}$ However, the rationale for

4 See, for example, United States $v$ Ishmael, 48 F3d 850, 851-52 (5th Cir), cert denied, 116 S Ct 74 (1995) (visual inspection and utility bills); United States $v$ Olson, 21 F3d 847, 848-49 (8th Cir), cert denied, 115 S Ct 230 (1994) (visual inspection and electrical records).

5 Wayne R. LaFave, 2 Search and Seizure: A Treatise on the Fourth Amendment $\S$ 4.2 at 151 (West $2 d$ ed 1987).

6 John Wesley Hall, Jr., 2 Search and Seizure § 42:10 at 698-99 (Clark, Boardman, Callaghan 2d ed 1993).

${ }^{7}$ See, for example, Ishmael, 48 F3d at 857; United States v Ford, 34 F3d 992, 997 (11th Cir 1994).

8 Anthony G. Amsterdam, Perspectives on the Fourth Amendment, 58 Minn L Rev 349,356 (1974).

9 See, for example, United States v Field, 855 F Supp 1518, 1533 (W D Wis 1994); State $v$ Young, 867 P2d 593, 594 (Wash 1994). 
these d.cisions shares similar flaws with the opinions upholding warrantless infrared imaging.

This Comment addresses the Fourth Amendment issues raised by the government's use of infrared imaging on private homes. ${ }^{10}$ Section I explains the scientific and technological aspects of infrared imaging crucial to a legal analysis. Section II examines the various judicial approaches to deciding whether warrantless infrared imaging violates the Fourth Amendment, and identifies the "technological approach" as the most productive means of analyzing whether infrared imaging is constitutional. Section III applies the technological approach and concludes that infrared imaging is a search within the meaning of the Fourth Amendment and should therefore be subject to judicial regulation.

\section{The Technologrcal Capabilities of Infrared Imagers}

As the sophistication of investigative technology increases, so do concerns that its warrantless use will violate Fourth Amendment rights. ${ }^{11}$ To illustrate this point, compare the qualitative difference between a hypothetical spy satellite that would allow the police to see through the walls of any structure on Earth and ordinary prescription eyeglasses worn by a police officer on duty. By enhancing vision, both devices allow police to spot activity that might otherwise remain private. But the spy satellite raises Fourth Amendment concerns far greater than any raised by the eyeglasses. The satellite device, unlike eyeglasses, could unobtrusively provide detailed information about the interior of the home.

The greater sense-enhancing capabilities of the spy satellite distinguish it from the eyeglasses. ${ }^{12}$ Therefore, a basic understanding of the capabilities of infrared imaging-what it can and cannot do-is essential to the issue of whether warrantless infra-

10 This Comment considers only the use of infrared imaging on homes. Used for other purposes in different contexts, infrared imaging may raise fewer concerns. See, for example, United States v Porter, 701 F2d 1158 (6th Cir 1983) (Defendants did not bring Fourth Amendment challenge to use of infrared surveillance to track plane.).

11 The Fifth Circuit recognized this relationship in United States $v$ Ishmael, 48 F3d 850,855 (5th Cir), cert denied, 116 S Ct 74 (1995) (" $[\mathrm{M}]$ ore sophisticated forms of technology increase the likelihood that their warrantless use will constitute an unreasonable intrusion.").

12 This Comment uses the phrase "sense-enhancing technology" to describe any device, such as the infrared imager, that "provides information not available to unaided sensory perceptions." See David E. Steinberg, Making Sense of Sense-Enhanced Searches, 74 Minn L Rev 563, 563 n 1 (1990) (defining "sense-enhanced search"). 
red imaging violates the Fourth Amendment. The capabilities of infrared imaging, in turn, depend on the source of the infrared radiation, the medium through which that radiation must travel, and the infrared imager itself.

\section{A. The Fundamentals of Infrared Radiation}

The capabilities of infrared imagers depend first on the physical properties of infrared radiation. Like visible light, infrared radiation is a form of electromagnetic radiation-"energy transmitted through space or through a material medium in the form of electromagnetic waves." In In frared radiation "obey[s] the same [physical laws] as those for visible light, radio waves, and $\mathrm{x}$ rays." ${ }^{14}$ The only fundamental difference between visible light and infrared radiation is the wavelength of the electromagnetic wave; infrared radiation has a longer wavelength than does visible light. ${ }^{15}$ This difference, however, is central to the legal analysis of infrared imaging because radiation interacts with matter differently depending on its wavelength. ${ }^{16}$ An infrared imager "sees" differently than the human eye because infrared radiation has a different wavelength than visible light.

In lay terms, infrared radiation is produced when an object emits heat. ${ }^{17}$ The emission of infrared radiation varies with the temperature of an object; as an object becomes hotter, it emits more infrared radiation. ${ }^{18}$ Infrared radiation, however, is not emitted solely by hot objects. All objects, even ice cubes, emit some infrared radiation. ${ }^{19}$ In fact, any object with a temperature above absolute zero $\left(0 \mathrm{~K}\right.$ or $\left.-273^{\circ} \mathrm{C}\right)$ emits infrared radiation. ${ }^{20}$

13 William R. Smythe, Electromagnetic radiation, in 6 McGraw-Hill Encyclopedia of Science \& Technology 162, 162 (McGraw-Hill 7th ed 1992); William L. Wolfe, Infrared radiation, in 9 McGraw-Hill Encyclopedia of Science \& Technology 167, 167 (McGraw-Hill 7th ed 1992).

14 John David Vincent, Fundamentals of Infrared Detector Operation and Testing 3 (Wiley 1990).

${ }^{15}$ W.L. Wolfe, Infrared Technology, in Robert A. Myers, ed, 8 Encyclopedia of Physical Science and Technology 127, 127 (Academic 2d ed 1992).

${ }^{16}$ See Melba Phillips, Electromagnetic Radiation, in 18 The New Encyclopaedia Britannica 292, 293 (Encyclopaedia Britannica 15th ed 1987).

${ }_{17}$ E.M. Sparrow and R.D. Cess, Radiation Heat Transfer 4 (Hemisphere 1978). More technically, infrared radiation is produced by the oscillation or acceleration of electrical charges in the atoms or molecules of an object. Smythe, Electromagnetic radiation at 162 (cited in note 13).

${ }^{18}$ Sparrow and Cess, Radiation Heat Transfer at 4 (cited in note 17); Wolfe, Infrared radiation at 167 (cited in note 13 ).

19 Vincent, Fundamentals of Infrared Detector Operation at 4 (cited in note 14).

${ }^{20}$ Henry L. Hackforth, Infrared Radiation 3, 14 (McGraw-Hill 1960). 
Consequently, infrared imaging, unlike human vision, does not depend on the reflection of radiation from sources such as sunlight or artificial illumination. Instead, infrared imaging depends primarily on detecting the radiation an object itself emits. Thus, the infrared imaging of a house is best conducted at night, when the daytime sun does not interfere with the image. ${ }^{21}$

An indoor marijuana-growing operation provides a sizeable source of infrared radiation. The operation often emits a substantial amount of radiation because, for successful indoor cultivation, growers must use incandescent heat lamps that simulate the sun's radiation. These lamps produce substantially more heat and infrared radiation than ordinary house lamps, and, therefore, infrared imaging often can detect indoor marijuana-growing operations. $^{22}$

\section{B. The Inner Workings of Infrared Imaging}

Although a house emitting a large amount of infrared radiation-such as one concealing a marijuana-growing operation-appears no different to the naked eye than a house emitting very little infrared radiation, by using infrared imaging, the police can convert "an invisible infrared image into a visible image." ${ }^{\text {23 }}$ An infrared imager has an optical head for receiving infrared radiation and a display that translates this radiation into a visual image. Thus the device is passive: it does not emit rays or beams but merely collects the infrared radiation emitted by an object. ${ }^{24}$ After the optical head picks up the infrared radiation, the imager translates the radiant signal into an electrical one. ${ }^{25}$ The electrical signal is then translated into a visible image on the imager's display. ${ }^{26}$ Warmer images appear increasingly lighter on the display. ${ }^{27}$ In addition, electronics can selectively

${ }^{21}$ See George J. Zissis, Infrared imaging devices, in 9 McGraw-Hill Encyclopedia of Science and Technology 163, 163 (McGraw-Hill 7th ed 1992).

${ }^{22}$ William Yelverton, Smoking Gun?, Tampa Trib North Pinellas 1 (Jan 29, 1995). The heat from these lamps can "cause structural temperature differences of $10^{\circ}-30^{\circ} \mathrm{C}$, revealing where growing operations take place and where heat is vented away or masked with insulation." Jerry R. Hobbs, Thermal Imaging: Thermal cameras help nab drug growers, Laser Focus World 28, 30 (June 1994).

${ }^{23}$ Zissis, Infrared imaging devices at 163 (cited in note 21).

24 Id at 164.

${ }_{25}$ Wolfe, Infrared Technology at 138 (cited in note 15).

${ }_{26}$ Zissis, Infrared imaging devices at 164 (cited in note 21).

${ }_{27}$ See John Stansell, Keeping watch on illegal nightlife, Sunday Times 9 (Oct 30, 1994). In order to visualize the image produced by an infrared device, it would be accurate to say that the "screen view is similar to that of the alien title character in the Arnold 
enhance or reduce features in the visible image produced. For example, the imager can assign different colors to different temperature levels, "so that a difference of a couple of levels in temperature shows on the screen as, say, a red area against a grey background."."28

Although the infrared imager displays only relative temperature differences, not absolute temperature, ${ }^{29}$ some models can register differences in temperature of as little as $0.1^{\circ} \mathrm{C} .^{30}$ Typically, infrared imaging can be displayed on a commercial television monitor and also recorded on a standard VCR. ${ }^{31}$ As a result, the police can present the actual image produced by the device to the magistrate in support of their request for a search warrant. ${ }^{32}$

To determine more accurately whether a particular structure conceals a marijuana-growing operation, the police may image neighboring houses to determine how much infrared radiation is being emitted by similar structures in similar climatic conditions. What distinguishes a house concealing a marijuana-growing operation is its heat profile-the pattern of infrared radiation emissions and the relative levels of those emissions-not the absolute value of radiation it emits. A dwelling that conceals a marijuanagrowing operation will generally exhibit a heat profile radically different from those of nearby homes. ${ }^{33}$

Schwarzenegger movie "Predator." Charles Stanley, Infrared tool helps cops stay out of $d a r k$, Chi Trib Section 2 at 3 (July 26, 1994).

${ }_{28}$ Graham Clayton, Infrared imager colours police's view, 140 New Scientist 22, 22 (Oct 9, 1993). See also Zissis, Infrared imaging devices at 164 (cited in note 21).

${ }_{29}$ Interview with Charles A. Stowell (Apr 17, 1994). Mr. Stowell is the director of Law Enforcement Services at AGEMA Enterprises, a manufacturer of infrared imaging equipment. He has thirty-one years of experience as an agent with the Drug Enforcement Agency and has testified as an expert witness in several of the infrared imaging cases discussed in this Comment.

30 Inframetrics FLIR Features IR, Color TV Sensors, Aviation Wk \& Space Tech 82, 82 (May 9, 1994) (advertisement).

31 Thermal Imaging Systems: Flir Systems, Portland, OR, 50 Materials Evaluation 690, 690 (1992) (advertisement).

${ }_{32}$ See Hobbs, Thermal Imaging, Laser Focus World at 28 (cited in note 22) (discussing police applications of infrared imaging).

${ }^{33}$ Interview with Charles Stowell (cited in note 29). Mr. Stowell adds that most magistrates prefer that the police conduct these additional infrared imagings to establish a basis for comparison. See, for example, United States $v$ Penny-Feeney, 773 F Supp 220, 223-24 (D Hawaii 1991), aff'd as United States v Feeney, 984 F2d 1053 (9th Cir 1993) (noting that police compared heat profile of suspect house with heat profiles of other homes to help establish probable cause). 
Depending on the model, the infrared imaging unit often resembles a small video camera. ${ }^{34}$ One model can be attached to the underside of an aircraft and controlled by a joystick in the cockpit. $^{35}$ Infrared images are available with effective ranges from approximately one hundred yards to five miles, and many allow the police to magnify the visible image to allow for better distance viewing. ${ }^{36}$ Thus, with currently available technology, police can unobtrusively perform infrared imaging, either from the ground or from a helicopter, of houses suspected of concealing marijuana-growing operations and of houses not suspected of any wrongdoing at all, and the occupants of these houses likely never even learn of the police presence. ${ }^{37}$

\section{Seeing through Walls? ${ }^{38}$}

Can infrared imaging devices see through the walls of a typical home or building? The simple answer is no. ${ }^{39}$ Infrared imagers cannot produce an image of an object or person inside the interior of a home. Infrared imaging can only indicate whether an enclosed structure contains a heat source, and from this information, police can draw inferences about activities occurring inside the structure's walls.

Because heat energy inevitably dissipates, it is impossible to conceal from an infrared imager the presence of a heat source, such as a person or a television set, inside an enclosed room. However, because infrared imaging devices cannot see through the walls of a home like an airport X-ray machine can see through the sides of a suitcase, it is possible to conceal the identity of that heat source. Infrared imaging will reveal the fact that an enclosed structure contains a heat source as well as the relative quantity of heat being produced, but it will not reveal any

34 Yelverton, Smoking Gun?, Tampa Trib North Pinellas at 1 (cited in note 22).

${ }^{35}$ Inframetrics FLIR, Aviation Wk \& Space Tech at 82 (cited in note 30 ).

${ }^{36}$ See Stansell, Keeping watch, Sunday Times at 9 (cited in note 27) (discussing the range of infrared technology).

37 Interview with Charles Stowell (cited in note 29).

38 Except as otherwise noted, the information in Sections I.C and I.D comes from several interviews with $\mathrm{Dr}$. Philip Coleman, who holds a $\mathrm{Ph} . \mathrm{D}$. in physics from the University of Wisconsin.

39 See United States $v$ Ishmael, 48 F3d 850, 856 (5th Cir), cert denied, 116 S Ct 74 (1995) (discussing the technological limitations of infrared imagers); United States $v$ Deaner, 1992 US Dist LEXIS 13046, *11 (M D Pa) (Infrared imaging is "incapable of providing definitive information as to what is happening behind closed doors other than the generation of heat."). 
more specific information about the kind of heat source it is detecting.

Infrared imagers cannot reveal information about the identities of heat sources inside an enclosed structure because, with the exception of some forms of plastic, ${ }^{40}$ common building materials are not transparent to infrared radiation. ${ }^{41}$ Wood, brick, plaster, concrete, and even glass are all opaque to infrared radiation and block infrared radiation in much the same way as concrete blocks visible light. ${ }^{42}$ Furthermore, the insulation that lines the external walls and the roofs of most structures is specifically designed to reflect infrared radiation back into the house. ${ }^{43}$

Although common building materials do not transmit infrared radiation directly, heat sources inside a structure will nonetheless cause the structure's exterior surfaces to emit infrared radiation. ${ }^{44}$ By detecting these indirect emissions, infrared imaging can reveal information about the activities within a structure. To illustrate, suppose a heat lamp and a person are inside an enclosed structure. Both the lamp and the person produce heat energy that is transferred to the walls of the structure through the processes of conduction, convection, and radiation. ${ }^{45}$ The

${ }^{40}$ See David P. Hodges, Note, Electronic Visual Surveillance and the Fourth Amendment: The Arrival of Big Brother?, 3 Hastings Const L Q 261, 269 (1976).

${ }^{41}$ For an infrared imager to produce a recognizable image of a heat source inside a closed space, the material with which the walls are constructed must be transparent to infrared radiation, such that most of the infrared radiation is transmitted directly through the material. More specifically, the material must be transparent to infrared radiation with a wavelength of either three to five microns or eight to twelve microns. These are the wavelengths of infrared radiation commonly generated by both natural and manmade objects. See Hackforth, Infrared Radiation at 107 (cited in note 20) (discussing natural and synthetic sources of infrared radiation). Not only is infrared radiation outside these two "atmospheric windows" less common, it is also completely absorbed by the gases in the atmosphere. See Vincent, Fundamentals of Infrared Detector Operation at 369 (cited in note 14) (discussing infrared windows). See also John Haystead, Thermal Imaging Technology Has Versatile and Bright Future, Def Electronics 49 (Apr 1991) (explaining differences in infrared wavelengths).

42 Interview with Charles Stowell (cited in note 29). It seems unlikely that houses will be made of plastic or, for that matter, any other material transparent to infrared radiation. Most structures are designed to retain heat during the winter months and to exclude heat during the summer months. To do so effectively, the material used as insulation must reflect infrared radiation in the desired direction, and any material that is transparent to infrared radiation is ill suited to this task.

${ }^{43}$ Harry F. Remde, Heat insulation, in $8 \mathrm{McGraw}$-Hill Encyclopedia of Science \& Technology 350, 350 (McGraw-Hill 7th ed 1992).

44 Interview with Charles Stowell (cited in note 29).

45 Ralph H. Luebbers, Heat transfer, in $8 \mathrm{McGraw-Hill} \mathrm{Encyclopedia} \mathrm{of} \mathrm{Science} \mathrm{\&}$ Technology 358, 358 (McGraw-Hill 7th ed 1992). Conduction involves "[t]he flow of thermal energy through a [physical] substance ... [by means of] atomic or molecular interac- 
transfer of heat energy to the walls increases their temperatures. As the walls become hotter, they emit more infrared radiation. In effect, the infrared radiation and heat energy from inside the structure are "reradiated" by the exterior surface of the structure. ${ }^{46}$ Thus, an infrared imager placed outside the structure produces a visible image of the radiation being emitted by the structure's exterior surfaces, but not an image of the interior objects originally producing that radiation. ${ }^{47}$

Moreover, this process of heat transfer is inevitable. The Second Law of Thermodynamics dictates that, as long as the atmosphere surrounding a structure is cooler than its interior, heat energy will inevitably be transferred to the atmosphere. ${ }^{48}$ No amount of insulation can prevent this transfer. ${ }^{49}$ Insulation slows heat transfer, but it cannot contain heat energy for an indefinite period of time. ${ }^{50}$

tions." Warren H. Giedt, Conduction (heat), in 4 McGraw-Hill Encyclopedia of Science \& Technology 304, 304 (McGraw-Hill 7th ed 1992). For example, heat energy will flow through the base of the lamp and the feet of the person into the floor of the structure, and then flow through the floor to the walls and roof. Convection involves the "actual physical movement from one location to another of a substance in which thermal energy is stored." Warren H. Giedt, Convection (heat), in $4 \mathrm{McGraw-Hill} \mathrm{Encyclopedia} \mathrm{of} \mathrm{Science} \mathrm{\&} \mathrm{Technol-}$ ogy 304, 304 (McGraw-Hill 7th ed 1992). For example, the lamp and the person will transfer heat energy to the air around them, and the warm air will in turn transfer heat to the walls. Lastly, infrared radiation, like any other form of electromagnetic radiation, "generates heat in any absorbing object lying in its path since it causes vibrations or rotations within the atomic structure of the object." Hackforth, Infrared Radiation at 3 (cited in note 20). Thus, the infrared radiation emitted by both the lamp and the person will radiate outward in all directions and be absorbed by the walls.

${ }^{46}$ See United States $v$ Penny-Feeney, 773 F Supp 220, 223-24 (D Hawaii 1991), aff'd as United States v Feeney, 984 F2d 1053 (9th $\mathrm{Cir}$ 1994) (heat indicated along walls).

47 An infrared imager may, however, reveal the approximate locations of heat sources inside a house. For example, if a person were hiding in an aluminum garden shed with his body pressed against the wall, the police would be able to detect the presence of a heat source closer to that wall than the others. However, infrared imaging could not determine whether the source was a person or a lawn mower. Interview with Charles Stowell (cited in note 29).

${ }^{18}$ See generally William F. Jaep, Thermodynamic principles, in $18 \mathrm{McGraw-Hill}$ Encyclopedia of Science \& Technology 302, 304-05 (McGraw-Hill 7th ed 1992).

${ }_{49}$ See generally Remde, Heat insulation at 350-51 (cited in note 43). Charles Stowell recounts a story of a indoor marijuana grower who lined his walls with three feet of insulation. Nevertheless, by using an infrared imager, the police were still able to identify the house as containing a marijuana-growing operation. Interview with Charles Stowell (cited in note 29).

so However, marijuana growers can take three measures to make their operations less noticeable to infrared imaging. First, they can use insulation to reduce the amount of heat energy necessary to grow a given crop. If they insulate sufficiently, they may be able to grow the same quantity of marijuana with fewer heat lamps, thereby decreasing the total amount of infrared radiation generated. Second, marijuana growers can vent the heat over a wider area. Because infrared imaging detects relative differences in infrared 


\section{Drawing Inferences from Infrared Imaging}

Notwithstanding its limitations, infrared imaging still informs through inference. Inferences from the presence of heat are commonplace. For example, if the hood of a car is warm to the touch, we might infer the car has recently been driven. Similarly, observing the infrared radiation emitted by the exterior surface of a structure allows the police to draw inferences about activities occurring inside. However, these inferences are not always accurate: the warm hood could have been heated by the sun. In each case, we would probably look for additional clues to corroborate our inferences. If, for example, we recently heard a car drive up and park, our inference about the car being driven would be more reliable.

Thus, it is only in a limited, inferential manner that infrared imaging can provide information about the interior of a house. Moreover, even the raw data provided by an infrared imager is generally inexact. While a house concealing a marijuana-growing operation will likely have an unusual heat profile-an ordinary house does not emit large quantities of heat from its basement-so might a house containing an indoor hot tub or a greenhouse for African violets. ${ }^{51}$ Thus, such a heat profile, although consistent with a marijuana-growing operation, is not necessarily proof of one.

In theory, if there were a thousand single-family houses of the same size, with the same number of occupants and major appliances, a police helicopter performing broad-area infrared imaging might.be able to identify the one house concealing a marijuana-growing operation. However, in practice, where the variation in infrared emissions and the number of heat sources in a typical neighborhood are great, such broad-area infrared imaging cannot consistently identify marijuana-growing operations. ${ }^{52}$ Consequently, infrared imaging again can only provide inexact information. The device can neither provide detailed information

emissions, a given amount of heat dispersed over a wide area is much less conspicuous than the same amount of heat emitted from a concentrated area. Finally, marijuana growers could simply turn off their heat lamps at night. Because interference from the sun hinders infrared imaging during the day, marijuana growers could reduce the likelihood of detection by turning off their lamps at night, particularly between one a.m. and sunrise.

${ }^{51}$ Tim Bryant, DEA Targets Indoor Pot Growers, St. Louis Post-Dispatch 10 (May 9, 1993) (recounting how police obtained a warrant to search an indoor orchid garden).

52 Interview with Charles Stowell (cited in note 29 ). 
about the interior of a structure, nor definitively determine if a particular house conceals a marijuana-growing operation.

\section{CURRent Legal ANALYSis AND ITS TECHNOLOGICAL SHORTCOMINGS}

Most courts that have addressed the issue have held that warrantless infrared imaging does not violate the Fourth Amendment. ${ }^{53}$ Several others have declined to decide the issue, ruling instead that the police established the probable cause required for a search warrant even without infrared imaging. ${ }^{54}$ Only a small number of courts have held that the Fourth Amendment prohibits warrantless infrared imaging. ${ }^{55}$

Although reaching different results, courts uniformly rely on the two-tiered analysis proposed by Justice Harlan in Katz $v$ United States ${ }^{56}$ to determine the constitutionality of warrantless infrared imaging. ${ }^{57}$ In Katz, the Court declared unconstitutional the government's warrantless use of an electronic device placed on the outside of a public phone booth to listen to the defendant's end of a telephone conversation. ${ }^{58}$ Specifically, it held that " $[t]$ he Government's activities in electronically listening to and recording the petitioner's words violated the privacy upon which he justifiably relied ... and thus constituted a 'search and seizure' within the meaning of the Fourth Amendment."59 Yet at the same time, the Katz Court acknowledged that "[w]hat a person knowingly exposes to the public, even in his own home or office, is not a subject of Fourth Amendment protection."

In a widely followed concurring opinion, Justice Harlan elaborated on the majority's rule: for the Fourth Amendment to pro-

53 See, for example, United States v Ishmael, 48 F3d 850, 857 (5th Cir), cert denied, 116 S Ct 74 (1995); United States v Ford, 34 F3d 992, 997 (11th Cir 1994). See also Section II.A.

s4 See, for example, United States v Pugh, 1994 US App LEXIS 25480, *2 (9th Cir), cert denied, 115 S Ct 1173 (1995); United States v Olson, 21 F3d 847, 849 (8th Cir), cert denied, 115 S Ct 664 (1994); United States $v$ Casanova, 835 F Supp 702, 708 (N D NY 1993).

ss See United States $v$ Field, 855 F Supp 1518, 1533 (W D Wis 1994); State v Young, 867 P2d 593, 594 (Wash 1994). See Section II.B.

${ }^{36} 389$ US 347, 361 (1967) (Harlan concurring).

57 Compare, for example, United States $v$ Pinson, 24 F3d 1056, 1058-59 (8th Cir), cert denied, 115 S Ct 664 (1994) (applying the Katz test to hold that warrantless infrared inspection is constitutional), with Ishmael, 843 F Supp at 209-13 (applying the Katz test to hold that warrantless infrared inspection is unconstitutional).

ss Katz, 389 US at 348, 358-59.

59 Id at 353 .

${ }^{\infty}$ Id at 351 . 
vide protection, "there is a twofold requirement, first that a person have exhibited an actual (subjective) expectation of privacy and, second, that the expectation be one that society is prepared to recognize as 'reasonable." ${ }^{61}$ Subsequently, in Smith v Maryland, the Court adopted Harlan's test, concluding that "the application of the Fourth Amendment depends on whether the person invoking its protection can claim a 'justifiable,' a 'reasonable,' or a 'legitimate expectation of privacy' that has been invaded by government action." ${ }^{22}$ Finally, in Oliver $v$ United States, the Court clarified Harlan's second prong, stating, "[t]he test of legitimacy is not whether the individual chooses to conceal assertedly 'private' activity[,] . . . [but r]ather . . . whether the government's intrusion infringes upon the personal and societal values protected by the Fourth Amendment." ${ }^{63}$ Thus, Katz and its progeny require a two-prong analysis: a defendant must show both a subjective and an objectively reasonable expectation of privacy.

Although the Katz test is not strictly dependent on the expectations of either a particular citizen or society as a whole, it is subject to a normative evaluation. In Smith, the Court noted that "[s]ituations can be imagined . . . in which Katz' two-pronged inquiry would provide an inadequate index of Fourth Amendment protection." The Court hypothesized that "if the Government were suddenly to announce on nationwide television that all homes henceforth would be subject to warrantless entry, individuals thereafter might not in fact entertain any actual expectation of privacy regarding their homes, papers, and effects." ${ }^{365}$ In situations "where an individual's subjective expectations had been 'conditioned' by influences alien to well-recognized Fourth Amendment freedoms, those subjective expectations obviously could play no meaningful role in ascertaining what the scope of Fourth Amendment protection was." Consequently, "a normative inquiry would be proper." ${ }^{\text {"67 }}$

Such a normative inquiry seems especially appropriate in analyzing infrared imaging, a subject about which society may have little understanding and few expectations. The threat here, as Smith seems to recognize, is that the gradual dissemination of

\footnotetext{
61 Id at 361 (Harlan concurring).

442 US 735, 740 (1979).

466 US 170, 182-83 (1984).

442 US at $740 \mathrm{n} 5$.

65 Id.

66 Id.

67 Id at 740-41 n 5 .
} 
infrared imaging equipment to police departments would condition society's expectations. Just because society may come to expect and accept police use of infrared imaging does not mean that society should accept warrantless use of infrared imaging. Smith, therefore, emphasizes the objectively reasonable prong of the Katz analysis. Courts should instead determine whether privacy interests are justifiable, reasonable, or legitimate, as suggested by Smith.

\section{A. Courts Upholding Warrantless Infrared Imaging}

Only four federal courts of appeals, applying Katz, have decided whether infrared imaging constitutes a search for purposes of the Fourth Amendment; all four have held that infrared imaging is not a search and is therefore not subject to the Fourth Amendment. ${ }^{68}$ Roughly three lines of reasoning have emerged from these courts: (1) the waste heat analogy, (2) the canine sniff analogy, and (3) the technological approach. As developed by these courts, none of these lines of reasoning is wholly satisfactory.

\section{The waste heat analogy.}

By analogizing excess heat to garbage, courts have held that the Fourth Amendment does not prohibit warrantless infrared imaging of homes. ${ }^{69}$ According to this "waste heat" analogy, since police can examine curbside garbage without a warrant, they can similarly examine heat that is "discarded" from the house.

The waste heat analogy stems from California $v$ Greenwood, in which the Supreme Court held that the Fourth Amendment

${ }^{68}$ United States $v$ Ishmael, 48 F3d 850, 857 (5th Cir), cert denied, 116 S Ct 74 (1995); United States v Myers, 46 F3d 668, 670 (7th Cir), cert denied, 116 S Ct 213 (1995); United States $v$ Ford, 34 F3d 992, 997 (11th Cir 1994); United States v Pinson, 24 F3d 1056, 1058-59 (8th Cir), cert denied, 115 S Ct 664 (1994). See also United States $v$ Robinson, 62 F3d 1325, 1329-30 (11th Cir 1995), citing Ford, 34 F3d at 996; United States $v$ Robertson, 39 F3d 891, 894 (8th Cir 1994), cert denied, 115 S Ct 1812 (1995), following Pinson, 24 F3d at 1058 .

See United States $v$ Myers, 46 F3d 668, 670 (7th Cir), cert denied, 116 S Ct 213 (1995); United States $v$ Ford, 34 F3d 992, 997 (11th Cir 1994); United States $v$ Pinson, 24 F3d 1056, 1058 (8th Cir), cert denied, 115 S Ct 664 (1994); United States v Porco, 842 F Supp 1393, 1397 (D Wyo 1994), aff'd on other grounds as United States $v$ Cusumano, 1996 US App LEXIS 10698 (10th Cir 1996); United States v Domitrovich, 852 F Supp 1460, 1474 (E D Wash 1994), aff'd, 57 F3d 1078 (9th Cir 1995); United States $v$ Penny-Feeney, 773 F Supp 220, 226 (D Hawaii 1991), aff'd as United States $v$ Feeney, 984 F2d 1053 (9th Cir 1993); State $v$ McKee, 181 Wis 2d 354, 510 NW2d 807, 810 (Ct App 1993). 
does not prohibit "the warrantless search and seizure of garbage left for collection outside the curtilage of a home." Re Reasoning that "[i]t is common knowledge that plastic garbage bags left on or at the side of a public street are readily accessible to animals, children, scavengers, snoops, and other members of the public," the Court concluded that placing trash on the curbside defeats a claim to Fourth Amendment protection because the garbage has been knowingly exposed to the public. ${ }^{71}$ Moreover, the act of taking trash to the curbside demonstrates a conscious decision to convey the garbage "to a third party, the trash collector. ${ }^{72}$ Accordingly, the Court held that the defendant's actions were inconsistent with a subjective expectation of privacy and that society does not recognize a reasonable expectation of privacy in garbage left at the curb.

The waste heat analogy to infrared imaging is valid only if the disposal of heat, like the disposal of garbage, can be properly characterized as both deliberate and preventable. However, the laws of thermodynamics support the opposite characterization: because dissipation is an inevitable consequence of heat production, it neither entails a deliberate act nor is preventable in the same way that one can conceal incriminating garbage. ${ }^{73}$ More fundamentally, though, the waste heat analogy does not address the fact that infrared radiation, unlike garbage, can only be detected by means of a technologically advanced device. The waste heat analogy is thus inexact, if not altogether inapposite.

The waste heat analogy implicates both prongs of the Katz test. In United States $v$ Ford, the defendant operated a marijuana-growing operation in his mobile home. ${ }^{74}$ In order to vent the heat generated by this activity, the defendant punched holes in the floor of the mobile home and installed both an electric blower and an air conditioner. Addressing the defendant's claim that warrantless infrared imaging of the mobile home violated the Fourth Amendment, the Eleventh Circuit found that the defendant had not exhibited a subjective expectation of privacy with respect to the dissipated heat; therefore, it held that the defendant's claim failed the first prong of the Katz test. The court concluded that "given [the defendant's] affirmative conduct to

786 US 35, 37 (1988).

71 Id at $40-41$ (citations omitted).

72 Id.

${ }^{73}$ See text accompanying notes $48-49$.

${ }^{34} 34$ F3d 992, 995 (11th Cir 1994). 
expel excess heat from his mobile home,... [the defendant] did not seek to preserve the fact of that heat as private." 75

The reasoning of the Ford court suggests that an individual who takes affirmative steps to vent heat cannot establish a subjective expectation of privacy regarding it. However, the Second Law of Thermodynamics holds that the heat generated by the defendant in Ford would have dissipated regardless of his actions. ${ }^{76}$ Moreover, venting can in some cases help to conceal heat from infrared imaging devices by dispersing it over a wider area. Consequently, venting could be seen as consistent with, not contrary to, a subjective expectation of privacy. Perhaps the Ford court meant that the deliberate venting of an amount of heat that is readily detectable by infrared imaging defeats a subjective expectation of privacy because "[w] hat a person knowingly exposes to the public, even in his own home or office, is not a subject of Fourth Amendment protection." ${ }^{177}$ Read this way, Ford reveals only what behavior is not protected by the Fourth Amendment; it says nothing about the circumstances in which the Fourth Amendment protects the generation or dissipation of heat from warrantless infrared imaging.

Thus, the question remains: under the reasoning of the waste heat analogy, what behavior is consistent with a subjective expectation of privacy? Unfortunately, the logical extension of Ford yields results that are lacking both legally and scientifically. If the deliberate venting of heat defeats the Fourth Amendment's protection, then an individual must contain her heat to protect her privacy. Yet, heat inevitably dissipates and cannot be forever contained. Under Ford, then, only an individual who incorrectly but sincerely believed that heat could be contained would have a subjective expectation of privacy. This approach thus strips anybody with a fundamental understanding of thermodynamics of her constitutional protection. Alternatively, perhaps an individual could have a subjective expectation of privacy in heat under Ford if she were to emit less radiation than what an infrared

${ }^{75}$ Id. Other courts have reached similar results. See Myers, 46 F3d at 669 (concluding that, because the defendant-" discharged the heat from his home through vents on his roof," he did not have "a subjective expectation of privacy in the heat emitted"); Domitrovich, $852 \mathrm{~F}$ Supp at 1473 (reasoning that because "[t]he defendant installed an exhaust fan which vented warm air from his grow [and thereby] knowingly exposed exhaust vapors and heat to public observation ... he cannot claim an actual expectation of privacy"); Penny-Feeney, 773 F Supp at 225 (ruling that the defendants "in no way attempted to impede escape or assert dominion" over the dissipated heat).

76 See text accompanying notes $45-49$.

77 Ford, 34 F3d at 995, quoting Katz, 389 US at 351. 
imager can detect. In this scenario, she would not be knowingly exposing her heat to the public. The waste heat analogy would thereby tie Fourth Amendment protection to the amount of heat energy a person generates and to the state of infrared imaging technology. But by doing so, Ford would refocus the analysis from expectations to heat production in seeming contradiction of the Katz analysis.

Because of the difficulty of reconciling the laws of physics with the first prong of the Katz test, other courts have instead focused their analysis on its second prong. ${ }^{78}$ Several courts have held that society does not recognize a legitimate expectation of privacy in waste heat. ${ }^{79}$ Thus, the court in United States $v$ Pen$n y$-Feeney concluded that "[b]oth [the disposal of garbage and waste heat] involve a homeowner's disposing of waste matter in areas exposed to the public." ${ }^{80}$ The court thought it unimportant that the heat was exposed only to those with sophisticated infrared imaging devices: "In Greenwood, the exposure was visual and the Court found that it was in no way diminished by the fact that the garbage was stored in opaque trash bags" whereas with infrared imaging "the exposure is heat-sensory and is in no way diminished by the fact that the source of the heat could only be detected by use of [an infrared imager]." ${ }^{81}$

By this logic, because it is widely known that heat dissipates, marijuana growers reasonably should know that the heat produced in their operations will be exposed to the public. ${ }^{82}$ To illustrate this point, the court in United States $v$ Domitrovich observed that widespread use of insulation in houses shows that most people intuitively understand this basic principle of thermo-

78 See, for example, United States $v$ Ishmael, 48 F3d 850, 854-55 (5th Cir), cert denied, 116 S Ct 74 (1995) (construing the first prong of the Katz test to be much less "restrictive" than Ford interpreted it to be in order to find that the defendants had an expectation of privacy under facts similar to those in Ford).

${ }^{79}$ For courts deciding on the ground that the defendant lacked an objective expectation of privacy, see Porco, 842 F Supp at 1397; Domitrovich, 852 F Supp at 1474. For courts holding that the defendant lacked both a subjective and an objective expectation of privacy, see Myers, 46 F3d at 669-70; Penny-Feeney, 773 F Supp at 226; Pinson, 24 F3d at 1058-59; Ford, 34 F3d at 997; United States $v$ Ward, 546 F Supp 300, 310 (W D Ark 1982), aff'd in part and rev'd in part, 703 F2d 1058 (8th Cir 1983). See also McKee, 510 NW2d at 810 (following Penny-Feeney).

${ }_{80} 773$ F Supp 220, 226 (D Hawaii 1991), aff'd as United States $v$ Feeney, 984 F2d 1053 (9th Cir 1993).

${ }^{81}$ Id. See also Ford, 34 F3d at 997, quoting Penny-Feeney, 773 F Supp at 226.

${ }_{82}$ See Domitrovich, 852 F Supp at 1474 (General knowledge that heat dissipates held relevant to whether exposure to public was knowing.). 
dynamics. ${ }^{83}$ Accordingly, the unavoidable process of venting heat into the atmosphere would constitute knowing exposure and defeat any claim to a reasonable expectation of privacy.

The waste heat analogy is fundamentally flawed because its reasoning is circular. The Court in Greenwood held that there is no objective expectation of privacy in curbside garbage in part because curbside garbage is readily accessible to any member of the public who wishes to inspect its contents. ${ }^{84}$ Thus, the validity of the waste heat analogy depends at least partially on accessibility. However, waste heat is only accessible to a person possessing sophisticated infrared imaging technology. ${ }^{85}$ Waste heat, unlike garbage, can only be exposed by means of infrared imaging, a technology not widely available to "children, scavengers, snoops, and other members of the public..86

Moreover, the waste heat analogy does not recognize the tension between fundamental scientific principles and its legal conclusions. The holding in Greenwood focuses on the deliberate and preventable action of placing trash on the curb for "public inspection and ... public consumption." ${ }^{37}$ Thus, before police can inspect garbage without a warrant under Greenwood, two deliberate and preventable acts must occur: (1) the production of garbage and (2) the placing of that garbage at the curb. By contrast, for waste heat to be subject to warrantless inspection, only one deliberate and preventable act must occur-the production of heat. Once produced, heat inevitably dissipates. Because garbage and heat have fundamentally different physical properties, an individual can maintain her privacy in garbage by simply keeping it in the house, but she cannot do the same for heat. ${ }^{88}$

The laws of physics prevent the courts from bringing infrared imaging squarely within the rationale of Greenwood. Ultimately, this tension in the waste heat analogy substantially undermines

83852 F Supp 1460, 1474 (E D Wash 1994), aff'd, 57 F3d 1078 (9th Cir 1995).

84 486 US at 40-41. See also Lisa J. Steele, Waste Heat and Garbage: The Legalization of Warrantless Infrared Searches, 29 Crim L Bull 19, 29 (1993) (characterizing Greenwood as holding no expectation of privacy where object readily accessible).

${ }_{85}$ Steele, 29 Crim L Bull at 29 (cited in note 84).

86 Greenwood, 486 US at 40 (citations and footnotes omitted).

87 Id at 40-41, quoting United States $v$ Reicherter, 647 F2d 397, 399 (3d Cir 1981).

See United States $v$ Field, 855 F Supp 1518, 1532 (W D Wis 1994) (finding it "illogical to conclude that any homeowner gives the same thought to the escape of heat from his or her home as he or she does to the removal of garbage from the home"). Other courts have also recognized the garbage analogy as unrealistic. See United States $v$ Ishmael, 843 F Supp 205, 213 (E D Tex 1994), rev'd, 48 F3d 850 (5th Cir), cert denied, 116 S Ct 74 (1995); State $v$ Young, 867 P2d 593, 602-03 (Wash 1994). 
its legitimacy. The waste heat analogy, therefore, cannot provide a forceful argument for the constitutionality of warrantless infrared imaging.

\section{The canine sniff analogy.}

Courts have also relied on an analogy to "canine sniffs" to support the holding that infrared imaging does not constitute a search for purposes of the Fourth Amendment. ${ }^{89}$ This analogy draws on the analysis in United States $v$ Place, where the Court held that the use of a trained drug-detecting dog to sniff luggage carried in a public place was not a search within the meaning of the Fourth Amendment. ${ }^{90}$ The Place Court emphasized the limited intrusiveness of the sniff and the limited information it provides. According to the Court, a canine sniff is a relatively unintrusive means of gathering information because it occurs quickly and does not expose noncontraband items to the police. As to content, the canine sniff provides information limited to "the presence or absence of narcotics." The "limited disclosure [of canine sniffs] also ensures that the owner of the [inspected luggage] is not subjected to embarrassment and inconvenience entailed in less discriminate and more intrusive investigative methods." The Court consequently held that "the particular course of investigation that the agents intended to pursue here-exposure of respondent's luggage, which was located in a public place, to a trained canine-did not constitute a 'search' within the meaning of the Fourth Amendment."93

Courts have extended Place to allow canine sniffs in contexts other than the examination of airport luggage. ${ }^{94}$ However, in United States $v$ Thomas, the Second Circuit observed that "[i]t is

89 See, for example, United States $v$ Robinson, 62 F3d 1325, 1330 (11th Cir 1995); United States $v$ Pinson, 24 F3d 1056, 1058 (8th Cir 1994), cert denied, 115 S Ct 664 (1995); State v McKee, 181 Wis 2d 354, 510 NW2d 807, 810 (Ct App 1993); United States $v$ Deaner, 1992 US Dist LEXIS 13046, *9-10 (M D Pa); Penny-Feeney, 773 F Supp at 226-27.

${ }_{90} 462$ US 696, 707 (1983). Though this conclusion was not necessary to the result in Place, the Court has since characterized its analysis as a "holding." United States $v$ Jacobsen, 466 US 109, 123-24 (1984).

91 Place, 462 US at 707.

92 Id.

93 Id.

94 See, for example, United States $v$ Solis, 536 F2d 880, 882-83 (9th Cir 1976) (upholding use of a canine sniff on a semi-trailer parked at a gas station); United States $v$ Lingenfelter, 997 F2d 632, 638 (9th Cir 1993) (upholding use of a canine sniff on the exterior of a warehouse fronting a public alleyway because it discloses no information about noncontraband items). 
one thing to say that a sniff in an airport is not a search, but quite another to say that a sniff can never be a search..95 In Thomas, the police used a dog to detect the smell of drugs emanating from underneath the front door of the defendant's apartment. Recognizing the "heightened privacy interest that an individual has in his dwelling place," the court found that the sniff violated the Fourth Amendment because the police had not first obtained a warrant. ${ }^{96}$ The court was particularly troubled by the ability of the dog to provide "information about what is inside a dwelling that [police] could not derive from the use of their own senses." 97

Place and Thomas suggest that at least two factors are relevant to the constitutionality of warrantless infrared imaging: the manner of obtaining information and the content of that information. Because technological limitations largely determine manner and content in the infrared imaging context, ${ }^{98}$ such limitations should also largely determine its constitutionality.

Both infrared imagers and drug-detecting dogs are senseenhancing devices. More explicitly, "[j]ust as odor escapes a compartment or building and is detected by the sense-enhancing instrument of a canine sniff, so also does heat escape a home and is detected by the sense-enhancing infrared camera." ${ }^{\text {"99 }}$ Dogs have a sense of smell "eight times as acute as that of humans," and therefore provide information about odors that police would not otherwise be able to detect. ${ }^{100}$ Analogously, infrared imagers allow police to "see" a spectrum of electromagnetic radiation that they would not otherwise be able to detect. ${ }^{101}$

By the logic of the canine sniff analogy, since there is no legitimate expectation of privacy in odors emitted from luggage, no reasonable expectation of privacy exists in heat emissions. ${ }^{102}$ Accordingly, if warrantless canine sniffs are inoffensive from a Fourth Amendment standpoint, then warrantless infrared imaging must be equally, if not more, acceptable because it also involves little embarrassment to the person and can likewise occur

95757 F2d 1359, 1366 (2d Cir 1985).

96 Id at 1366-67.

97 Id at 1367.

${ }^{98}$ See text accompanying notes 38-50.

${ }^{99}$ Pinson, 24 F3d at 1058.

${ }^{100} \mathrm{McKee}, 510 \mathrm{NW} 2 \mathrm{~d}$ at 810.

101 See text accompanying notes 13-16.

102 Deaner, 1992 US Dist LEXIS 13046, *8-9. 
without interfering with a person's activities. ${ }^{103}$ As one district court has concluded, "the use of [an infrared imager] from a plane flying above a house is less offensive and embarrassing than use of marijuana-sniffing dogs, which must be accompanied by government agents and which must perform their work in a very close proximity to the target structure."104

At least one court, however, has recognized a flaw in this analogy: infrared imaging provides open-ended information about heat emissions from all sources-both legal and illegal-whereas canine sniffs only provide information about the presence of illicit substances. ${ }^{105}$ An infrared imager, unlike a drug-detecting dog, cannot limit its detection to information regarding illegal activities. ${ }^{106}$ This difference undermines the analogy because "[t]here is no law regulating how much heat a residence may emit and the radiation of an unusual amount of heat cannot lead directly to an inference of illegal activity in the same direct manner as the smell of contraband implies its presence."107

Nonetheless, the emphasis that courts place on the degree of intrusiveness in the canine sniff context seems appropriate to a Fourth Amendment analysis of infrared imaging. Yet, courts applying the analogy to infrared imaging have misconstrued the insight revealed by Place. That infrared imaging can be performed unintrusively-that is, it does not interfere with the person or his daily activities-does not mean that it is unintrusive. For example, a camera that permitted the police to see through walls would work unintrusively because it would not interfere with a person's activities, but such use would reveal intimate details about the interior of the home and therefore invade the privacy interests of those inside. Moreover, unintrusive examinations are not necessarily more desirable than intrusive ones. Intrusive surveillance and investigative techniques often serve to publicize police actions, and thereby allow citizens to monitor the activities of their police force. ${ }^{108}$ Less intrusive examinations

103 McKee, 510 NW2d at 810.

104 Deaner, 1992 US Dist LEXIS 13046, *11.

105 Domitrovich, 852 F Supp at 1475.

106 See United States v Field, 855 F Supp 1518, 1533 (W D Wis 1994) ("[A] properly trained drug sniffing dog is more precise than a heat imager because the dog is trained to alert only to contraband" whereas "[a] thermal imager visualizes all the heat it registers, regardless of the source of radiation.").

${ }_{107}$ Steele, 29 Crim L Bull at 31 (cited in note 84).

108 Steinberg, 74 Minn L Rev at 572-74 (cited in note 12). See also Field, 855 F Supp at 1533 (arguing that because "[d]rug sniffing dogs normally work close in, . . . a homeowner has some protection from the random use of a drug sniffing dog"). 
may therefore raise more, not fewer, Fourth Amendment concerns.

Finally, the canine sniff analogy, like the waste heat analogy, fails to address directly the constitutionality of warrantless infrared imaging. The mere fact that an imager can detect infrared radiation like a dog can detect odor does not justify its warrantless use. Unlike canine sniffs, infrared imaging does not provide information limited to the presence or absence of contraband. Instead, infrared imaging provides inexact information subject to inference. Without a more careful consideration of these differences, the canine sniff analogy, like the waste heat analogy, fails to provide a strong argument for the constitutionality of warrantless infrared imaging. It simply fails to confront the technological capabilities and limitations of infrared imagers.

\section{The technological approach.}

Courts employing the most compelling reasoning to support the conclusion that infrared imaging is not a search have looked closely at the underlying technological and scientific principles. These courts have held that infrared imaging is not a search because the technology cannot reveal "intimate details" about the activities inside the home. ${ }^{109}$ These technological arguments derive from principles drawn from Supreme Court precedent. Although the Court has never considered the constitutionality of warrantless infrared imaging, it has considered the warrantless use of similar high-technology devices. ${ }^{110}$ Of these decisions, Dow Chemical Co. $v$ United States ${ }^{111}$ is perhaps the most helpful in the infrared imaging context.

In that case, Dow Chemical objected to the warrantless aerial observation by the Environmental Protection Agency ("EPA") of its two thousand-acre manufacturing facility. ${ }^{112}$ Dow "maintained elaborate security around the perimeter of the complex

109 See Ford, 34 F3d at 996.

110 See, for example, Florida v Riley, 488 US 445, 448-50 (1989) (use of a helicopter); California v Circolo, 476 US 207, 209 (1986) (airplane and standard 35-mm camera); Dow Chemical Co. $v$ United States, 476 US 227, 229 (1986) (precision aerial mapping camera); United States v Karo, 468 US 705, 711-13 (1984) (electronic tracking device); United States $v$ Knotts, 460 US 276, 284-85 (1983) (electronic tracking device); Smith, 442 US at 741-44 (device that recorded numbers dialed on a telephone); Air Pollution Variance Board $v$ Western Alfalfa Corp, 416 US 861, 863-65 (1974) (test to measure opacity of smoke); Katz, 389 US at 351-53 (listening equipment).

111476 US 227 (1986).

112 Id at 229-30. 
barring ground-level public views ... [and] investigate[d] any low-level flights by aircraft over the facility." ${ }^{113}$ However, Dow did not "conceal all manufacturing equipment within the complex from aerial views." ${ }^{\prime 14}$ The EPA flew over the facility to take pictures of the site with "the finest precision aerial camera available[, which] permitted [the] EPA to capture on film a great deal more than the human eye could ever see."115 In response to Dow Chemical's claim that such activity required a warrant, the majority held "that the taking of aerial photographs of an industrial plant complex from navigable airspace is not a search prohibited by the Fourth Amendment."116

Although raising other issues, the majority rested its conclusions at least partially on the limitations of the technology involved-the plane and the camera. The Court noted that the "EPA was not employing some unique sensory device that, for example, could penetrate the walls of buildings ... but rather a conventional, albeit precise, commercial camera commonly used in mapmaking." ${ }^{117}$ Significantly, the Court noted that a warrant might be required if the police used "highly sophisticated surveillance equipment not generally available to the public, such as satellite technology," but is not when "the photographs ... are not so revealing of intimate details as to raise constitutional concerns." man vision is enhanced somewhat, at least to the degree here, does not give rise to constitutional problems," recognized that the Fourth Amendment issues raised by sensoryenhanced surveillance largely turn on technological line drawing. In deciding whether to require a warrant, courts must consider the degree to which a particular device infringes upon privacy interests.

In deciding the constitutionality of warrantless infrared imaging, the Fifth Circuit, in United States $v$ Ishmael, ${ }^{120}$ followed the approach of Dow Chemical. The Ishmael court carefully considered the capabilities of infrared imagers and correctly rejected the notion that an infrared imager "is the functional equiv-

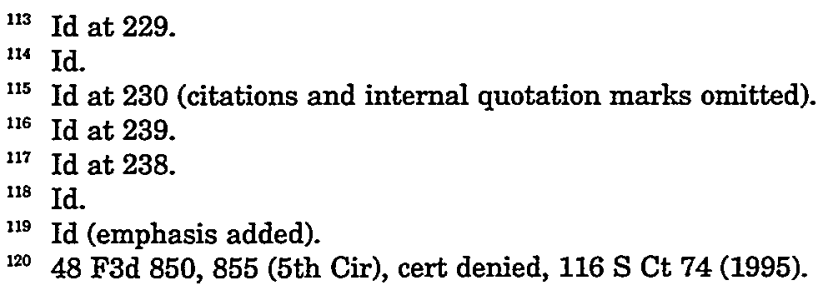


alent of an X-ray machine."121 The court consequently upheld the constitutionality of warrantless infrared imaging. The court considered the capabilities of the technology involved and arrived at the legal conclusion that infrared imaging is not a search, particularly because the device operates passively and reveals no intimate details of personal life within a structure. ${ }^{122}$

Other courts have similarly concluded that infrared imaging is noninvasive because it "does not penetrate the viewed object, nor does it emit rays or beams of any type."123 These courts have noted that infrared imagers do not reveal "intimate details connected with the use of the home or curtilage." 224 By taking a closer look at the technology, courts have shifted the focus to "the character of the information actually revealed." 125 In doing so, courts have correctly noted that the infrared imager "is incapable of providing definitive information as to what is happening behind closed doors other than the generation of heat."126 Because of this limitation, "no intimate details of the home [are] observed, and there [is] no intrusion upon the privacy of the individuals within." 22 In addition, infrared imaging "entails no embarrassment to or search of the person." 28 Thus, "[n]one of the interests which form the basis for the need for protection of a residence, namely the intimacy, personal autonomy and privacy associated with a home, are threatened by thermal imagery."

Unlike the waste heat and canine sniff approaches, the technological approach at least addresses the underlying questions that inform the constitutionality of infrared imaging. This approach engages in a technological line-drawing process similar to that in Dow Chemical. By considering whether infrared imaging reveals "intimate details" and thereby intrudes on privacy, the technological approach attempts to define the point at which advanced technology reveals so much that its warrantless use violates the Fourth Amendment.

121 Id at 856.

122 Id at 857.

${ }^{123}$ United States $v$ Myers, 46 F3d 668, 669 (7th Cir), cert denied, 116 S Ct 74 (1995).

See also United States $v$ Pinson, 24 F3d 1056, 1058-59 (8th Cir), cert denied, 115 S Ct 664

(1994) (finding infrared imaging to be nonintrusive).

126 See, for example, Ford, 34 F3d at 996, quoting Riley, 488 US at 452.

125 Domitrovich, 852 F Supp at 1475.

${ }^{126}$ Deaner, 1992 US Dist LEXIS 13046, *11 (emphasis added).

127 Ishmael, 48 F3d at 856, quoting Pinson, 24 F3d at 1059.

${ }^{228}$ State v McKee, 181 Wis 2d 354, 510 NW2d 807, 810 (Ct App 1993).

129 Pinson, 24 F3d at 1059. 


\section{B. Courts Holding Warrantless Infrared Imaging Impermissible}

Not all courts have upheld warrantless infrared imaging. At least three courts have concluded that infrared imaging constitutes a search for purposes of the Fourth Amendment and that therefore a warrant is required. ${ }^{130}$ While two of these decisions have been reversed or overruled, ${ }^{131}$ the opinions are important because they reveal judicial misconceptions about the technological capabilities of infrared imagers. Moreover, even though they misconceive the technological capabilities of infrared imagers, these decisions, by considering the content of the information revealed by infrared imaging, lend further support to the technological approach.

In holding warrantless infrared imaging unconstitutional, these courts have focused on the ability of infrared imaging to reveal information about the interior of the home. ${ }^{132}$ In State $v$ Young, the Supreme Court of Washington required a warrant for the use of infrared imaging because, in its opinion, the device revealed intimate details that could not be observed outside the curtilage of the home. ${ }^{133}$ The Young court characterized the device as producing "an image of the interior of the home that otherwise is protected by the home's walls," and as allowing the "government to intrude into the defendant's home and gather information about what occurs there."134 Similarly, the district court in United States $v$ Field recognized that "the imager records the heat escaping from the walls that is emitted by an object on

130 United States $v$ Field, 855 F Supp 1518, 1533 (W D Wis 1994); United States $v$ Ishmael, 843 F Supp 205, 213 (E D Tex 1994), rev'd, 48 F3d 850 (5th Cir), cert denied, 116 S Ct 74 (1995); State $v$ Young, 867 P2d 593, 594 (Wash 1994).

131 United States $v$ Myers, 46 F3d 668, 670 (7th Cir), cert denied, 116 S Ct 213 (1995) (holding infrared scanning not to be a search but not explicitly overruling Field); Ishmael, 48 F3d at 857 (reversing lower court).

${ }_{132}$ See, for example, Field, $855 \mathrm{~F}$ Supp at 1531 . This line of reasoning finds support in two Supreme Court decisions involving electronic "beepers," a type of radio transmitter that emits traceable signals. In United States $v$ Knotts, the Court upheld the warrantless use of a beeper to track a car, reasoning that the "governmental surveillance conducted by means of the beeper in this case amounted principally to the following of an automobile on public streets and highways." 460 US 276, 281 (1983). Subsequently, however, the Court held in United States $v$ Karo that "the monitoring of a beeper in a private residence, a location not open to visual surveillance, violates the Fourth Amendment rights of those who have a justifiable interest in the privacy of the residence." 468 US 705,714 (1984). The Karo Court concluded that a violation of the Fourth Amendment occurs whenever, without a warrant, "the Government surreptitiously employs an electronic device to obtain information that it could not have obtained by observation outside the curtilage of the house." Id at 715.

133867 P2d 593, 603-04 (Wash 1994).

134 Id at 603. 
the other side of the wall," and concluded that "[t]o the extent the device can pick up such radiation ... it can 'see through' walls." ${ }^{" 135}$ As a result, the Field court declared warrantless infrared imaging unconstitutional because "[t]hermal imaging can extract information from within a person's home, the place most deserving of protection from government intrusion."

In support of their conclusions, these courts have engaged in the technological line-drawing set forth in Dow Chemical. ${ }^{137}$ In United States $v$ Ishmael, the district court found that "the thermal imaging equipment used by the government in this case was exactly the type of sophisticated technology that concerned the Supreme Court, and was therefore excepted from the Dow opinion's approval for warrantless searches."138 The Young court drew a similar line, observing that "an infrared device need not produce the equivalent of a photographic image before it is declared intrusive under the Fourth Amendment."139 The Young court noted that "[t]he device can detect a human form through an open window when [1)] the person is leaning against a curtain, and [2)] pressing the curtain between the window screen and his or her body." ${ }^{140}$ Finally, the court seemed troubled that the infrared device revealed the "specific location of heat sources within the home."

These decisions emphasize, but overstate, the technological capabilities of infrared imaging. Infrared imagers cannot see through walls; they merely detect the infrared radiation that is produced by heat sources within a structure and then reradiated by the exterior surfaces of that structure. As a result, infrared imaging can reveal the presence, but not the identity, of a heat source. ${ }^{142}$ Because these courts seem to mistake infrared imagers for some form of "X-ray imaging," their technological

135855 F Supp 1518, 1519 (W D Wis 1994).

136 Id.

137 See notes 117-19 and accompanying text.

${ }^{138} 843$ F Supp 205, 212 (E D Tex 1994), rev'd, 48 F3d 850 (5th Cir), cert denied, 116 S Ct 74 (1995).

139867 P2d at 602.

${ }_{100}$ Id at 595 (emphasis added). If, however, the window were closed, police could not detect the human form because glass is opaque to infrared radiation. See text accompanying note 42.

141 See Young, 867 P2d at 602. See also Field, 855 F Supp at 1519 ("In this case, for instance, the imager recorded the thermal energy emitted by a dehumidifier inside a closet within defendant's residence. The imager did not reveal that the heat emitting source was a dehumidifier, but it did reveal facts about activities within the house: the fact of the heat emission and its general location.").

${ }^{142}$ See notes 38-40 and accompanying text. 
analyses do not necessarily support their holdings. It is unclear whether these holdings depend on the (mistakenly) perceived ability of infrared imagers to see through walls, or whether the ability to detect infrared radiation emitted from the exterior walls of a home is sufficiently intrusive, in itself, to be unconstitutional.

In United States $v$ Cusumano, however, a panel of the Tenth Circuit addressed this point directly. ${ }^{143}$ While the panel's opinion was vacated upon rehearing en banc, ${ }^{144}$ its reasoning is nonetheless illustrative of the technological approach to the constitutionality of warrantless in infrared imaging. Specifically, the panel recognized that the infrared imager could not see through walls per se, but instead correctly noted that the device "records heat gradients across the exterior surface of a building." 145 The court also correctly recognized that "[ $t]$ he laws of thermodynamics inform us that the amount of heat radiated from a given section of the exterior wall is directly related to the amount of heat generated by heat sources in proximity to the interior of that wall." ${ }^{146}$ Therefore, the court appropriately framed its analysis by focusing on the issue of whether "the link between the 'waste heat' observed by the imager and the activities that gave rise to that heat [are] so attenuated as to restrict the 'expectation of privacy' analysis to the heat alone."147

The court answered this question in the negative. It concluded that infrared imaging could provide sufficiently detailed information about the interior of the home that an individual had a reasonable expectation of privacy in his heat. In other words, the nexus between the waste heat and the activities that produce such heat are sufficiently close to qualify for Fourth Amendment protection. The "rather specific information regarding the internal activities of the home" and the inferences drawn therefrom thus "strips the sanctuary of the home of one vital dimension of its security: the 'right to be let alone' from the arbitrary and

${ }^{143} 67$ F3d 1497 (10th Cir 1995), vacated, 1996 US App LEXIS, *12 (10th Cir 1996).

144 United States v Cusumano, 1996 US App LEXIS 10698, *12 (10th Cir 1996). Like the panel, the en banc court affiirmed the defendants' convictions. Unlike the panel, however, the en banc court did so on the ground that there was ample evidence independent of the thermal imaging to establish probable cause for the search warrant issued in that case. Id $* 2,12$. the en banc court explicitly declined to "decide whether the use of a thermal imager to detect heat emissions from a personal residence constitutes a search under the Fourth Amendment." Id *2-3.

$14567 \mathrm{~F} 3 \mathrm{~d}$ at 1501.

166 Id.

147 Id. 
discretionary monitoring of our actions by government offcials. ${ }^{\text {"148 }}$

The court, however, seemed to base much of its analysis on as yet unrealized technological advancements ${ }^{149}$ and seemed most concerned with setting a precedent to prevent the "march of science" from trampling the protections guaranteed by the Fourth Amendment. ${ }^{150}$ The court feared that if it did not take a strong stand now, "the government would allow the privacy of the home to hinge upon the outcome of a technological race of measure/counter-measure between the average citizen and the government...."151 While this may overstate the current concerns, ultimately Cusumano is the most thoughtful exposition of the Fourth Amendment concerns raised by infrared imaging to date.

\section{ADOPTING THE TECHNOLOGICAL APPROACH}

Notwithstanding the scientific confusion apparent in some infrared imaging decisions, the technological approach rightly focuses on the capabilities and limitations of infrared imagers. Unlike the waste heat and canine sniff analogies, the technological approach recognizes that courts must first understand what information is revealed by a particular sense-enhancing technology before they can assess its constitutional implications. Furthermore, the technological approach does not focus strictly on the manner of obtaining the information. Instead, it focuses on the extent to which infrared imaging invades individual privacy. In doing so, the technological inquiry attempts to draw an appropriate line between legitimate and illegitimate uses of sense-enhancing devices.

To undertake this technological line-drawing, courts must ask to what extent infrared imaging "infringes upon the personal and societal values protected by the Fourth Amendment." Specifically, courts must decide whether warrantless infrared imaging infringes upon these values to such an extent that it constitutes a search requiring judicial oversight. Under this approach, then, the determinative factors are the values embodied

${ }^{148}$ Id at 1504 (citation and footnote omitted).

${ }^{149}$ See, for example, id at $1502 \mathrm{n} 7$ (discussing hypothetical devices with greater surveillance capabilities).

150 Id at 1505.

151 Id at 1504.

152 Oliver, 466 US at $182-83$. 
by the Fourth Amendment and the extent to which the use of infrared imagers infringes upon those values.

This Comment argues that infrared imaging of homes does constitute a search within the meaning of the Fourth Amendment. In other words, infrared imaging of homes infringes the values embodied in the Fourth Amendment to such an extent that courts should oversee police use of infrared imagers. Although the Court has determined when other investigative devices and practices are consistent with the Fourth Amendment, those other devices and practices are, at best, imperfect analogies to infrared imaging. Because the technological capabilities of infrared imaging implicate a unique set of privacy concerns, courts must examine these capabilities and their effects on privacy to determine whether infrared imaging is constitutional.

\section{A. The Values Embodied in the Fourth Amendment}

The Fourth Amendment "invites treatment as a broad statement about the relationship between an individual and the government."153 To achieve societal goals, the government must often restrict personal autonomy, but the Fourth Amendment ensures that "the value of personal autonomy is given permanence and secured against the changing demands of social policy."154 It thus protects the individual against arbitrary and oppressive conduct by the government, especially invasive police action. ${ }^{155}$ This protection affords the individual a measure of pri-vacy-a value that lies at the core of the Fourth Amendment. ${ }^{156}$

The Fourth Amendment's limitations on general searches evince this concern over arbitrary and oppressive police activi-

${ }^{153}$ Lloyd L. Weinreb, Generalities of the Fourth Amendment, $42 \mathrm{U}$ Chi L Rev 47, 47 (1974).

154 Id.

165 John Wesley Hall, Jr., 1 Search and Seizure $\S 1: 18$ at 27 (Clark, Boardman, Callaghan 2d ed 1991).

${ }^{156}$ For a discussion of the relationship between the Fourth Amendment and privacy, see Melvin Gutterman, A Formulation of the Value and Means Models of the Fourth Amendment in the Age of Technologically Enhanced Surveillance, 39 Syracuse L Rev 647, 707 (1988); James J. Tomkovicz, Beyond Secrecy for Secrecy's Sake: Toward an Expanded Vision of the Fourth Amendment Privacy Province, 36 Hastings L J 645, 649 (1985); Lewis R. Katz, In Search of a Fourth Amendment for the Twenty-first Century, 65 Ind L J 549, 559-60 (1990). The Supreme Court, however, has suggested that the Fourth Amendment is not solely concerned with privacy. See Katz, 389 US at 350 (The Fourth Amendment "cannot be translated into a general constitutional 'right to privacy.' That Amendment protects individuals against certain kinds of governmental intrusion, but its protections go further, and often have nothing to do with privacy at all."). 
ty. ${ }^{157}$ Indeed, the Fourth Amendment ensures that the most intrusive police activities are reserved for cases in which particular individuals are suspected of specific criminal activity. ${ }^{158}$ To search a private place, the police must have a compelling need capable of being stated with particularity and must be able to show cause for why they are searching the particular person, place, or thing. ${ }^{159}$ The text of the Fourth Amendment clearly expresses this particularity requirement, by mandating that no warrants be issued except those "particularly describing the place to be searched, and the persons or things to be seized."

The particularity concern, however, extends beyond the requirements for issuance of a warrant. The Fourth Amendment proscribes indiscriminate police actions that approach the level of a general search. ${ }^{161}$ The particularity concern suggests that, as police activity focuses on individuals not legitimately suspected of wrongdoing, the activity is more likely to encroach upon the values protected by Fourth Amendment. ${ }^{162}$ Thus, for example, the inspection, in an airport, of a suitcase belonging to a person legitimately suspected of smuggling cocaine is less problematic, from the standpoint of the Fourth Amendment, than random or even systematic inspections of luggage carried by any person who leaves her home.

The Fourth Amendment serves several instrumental ends. To insure its continued existence, a constitutional democracy must provide for the privacy of its citizens and the openness of its institutions. ${ }^{163}$ Publicizing governmental actions restrains governmental power, while protecting the privacy of citizens provides a sphere for individual development. To perform this

157 Weinreb, 42 U Chi L Rev at 50-51 (cited in note 153); Gutterman, 39 Syracuse L Rev at 723 (cited in note 156). See also Shirley M. Hufstedler, Invisible Searches for Intangible Things: Regulation of Governmental Information Gathering, $127 \mathrm{U} \mathrm{Pa} \mathrm{L}$ Rev 1483, 1486-92 (1979) (discussing the historical origins of the Fourth Amendment prohibition against general warrants).

${ }^{153}$ Gutterman, 39 Syracuse L Rev at 723 (cited in note 156).

159 Weinreb, $42 \mathrm{U}$ Chi $\mathrm{L}$ Rev at 51 (cited in note 153). For cases applying the particularity requirement, see Steele $v$ United States No. 1, 267 US 498, 503 (1925); Maryland $v$ Garrison, 480 US 79, 88 (1987).

160 US Const, Amend IV.

I61 See, for example, Michigan v Clifford, 464 US 287, 296-99 (1984) (plurality opinion); Mincey $v$ Arizona, 437 US 385, 395 (1978); United States v Lefkowitz, 285 US 452, 464-66 (1932). See also Steinberg, $74 \mathrm{Minn} L \mathrm{~L}$ Rev at 575-76 (cited in note 12) (discussing the Fourth Amendment prohibition against general searches).

162 Steinberg, 74 Minn L Rev at 574-82 (cited in note 12).

163 In contrast, more repressive governments closely watch their citizens and keep their own actions secret. Gutterman, 39 Syracuse L Rev at 705 (cited in note 156). 
function, however, the right to privacy need not be absolute. In fact, an absolute right to privacy and autonomy would undermine social institutions by eviscerating necessary social controls. ${ }^{164}$ Thus, a constitutional democracy must strike an appropriate balance between privacy and governmental power.

The Fourth Amendment serves the ends of constitutional democracy by carving out a sphere in which the citizen can take advantage of the full range of rights guaranteed by the Constitution. For example, privacy grants an individual a sphere in which to form opinions, express ideas, and join organizations free from the watchful eye of the government. ${ }^{165}$ The exercise of such First Amendment rights often depends on keeping these matters unknown to the government, and government observation may have a chilling effect on the exercise of such privacy-dependent rights. ${ }^{166}$

By providing citizens with a sphere of privacy free from most governmental intrusions, the Fourth Amendment serves a noninstrumental value as well. Citizens place a value on this privacy if for no other reason than because "comfort and contentment ... can be derived simply from the availability of such a private sphere."167 In the Fourth Amendment context, this privacy can take on several meanings. ${ }^{168}$ For purposes of considering infrared imaging, the two most important forms of privacy are solitude and anonymity. The former is the most basic form of privacy; it results when an individual or group of individuals can seclude himself or themselves from observation. But anonymity also provides the comfort and contentment of privacy. Anonymity occurs "when the individual is in public places or doing public things but still seeks, and finds, freedom from identification and surveillance." 169 In modern society, the preservation of privacy increasingly depends on blending into the "situational landscape" rather than on remaining unobserved. ${ }^{170}$ Thus, even in public

164 See Alan F. Westin, Science, Privacy, and Freedom: Issues and Proposals for the 1970's, 66 Colum L Rev 1003, 1019-20 (1966).

165 Id at 1019.

${ }^{165}$ Tomkovicz, 36 Hastings $L \mathrm{~J}$ at 667 (cited in note 156); Steinberg, 74 Minn L Rev at 570-71 (cited in note 12).

${ }_{167}$ Tomkovicz, 36 Hastings $\mathrm{L} J$ at 668 (cited in note 156). But Tomkovicz goes on to suggest that "comfort and contentment" cannot be the sole objects of the Fourth Amendment. Id at 668-69.

${ }^{163}$ Indeed, one commentator has identified four possible meanings: solitude, intimacy, anonymity, and reserve. See Westin, 66 Colum $L$ Rev at 1020-22 (cited in note 164).

169 Id at 1021.

170 See id (employing the term "situational landscape"). 
places, the individual can find comfort and contentment as long as the government is not systematically watching and recording her movements and actions.

\section{B. Technology and Fourth Amendment Values}

As the sophistication of technology increases so too does the potential threat to Fourth Amendment values. ${ }^{171}$ While senseenhancing technology can boost the effectiveness of law enforcement agencies, it can also undermine a constitutional democracy. First, insofar as courts permit the use of sense-enhancing technology, its use can narrow the sphere of protected privacy and thereby undermine comfort and contentment. When citizens feel less protected from surveillance, ${ }^{172}$ they will likely feel less comfortable undertaking, and less willing to engage in, activities beneficial to both the individual and society. ${ }^{173}$

Second, by enhancing the government's ability to observe unobtrusively the activities of private citizens, infrared imaging disrupts the appropriate balance between privacy and government accountability. ${ }^{174}$ For example, infrared imaging can be conducted from a helicopter hovering more than a mile from the house being observed. Because there is little chance that anyone will notice the helicopter, the actions of the police force will go undetected. Thus, as technology advances, the government can

${ }^{171}$ Clifford S. Fishman, Technologically Enhanced Visual Surveillance and the Fourth Amendment: Sophistication, Availability and the Expectation of Privacy, $26 \mathrm{Am}$ Crim L $\operatorname{Rev} 315,323$ (1988) (noting the direct correlation between the degree of sense enhancement and the likelihood that a court will hold a technique to be a search).

Of course, because the limitations of human sensory perception provide the baseline against which sense-enhancing technology must necessarily be compared, the constitutionality of the warrantless use of sense-enhancing technology depends on the limitations of the human senses as well as on the capabilities of the sense-enhancing technology employed. Weinreb, $42 \mathrm{U}$ Chi L Rev at 83 (cited in note 153).

172 See Robert C. Power, Technology and the Fourth Amendment: A Proposed Formulation for Visual Searches, $80 \mathrm{~J}$ Crim L \& Criminol 1, 102-03 (1989) (discussing how the dissemination of sense-enhancing technology reduces the individual's expectation of privacy); Don Mayer, Workplace Privacy and the Fourth Amendment: An End to Reasonable Expectations?, 29 Am Bus L J 625, 638-44 (1991) (discussing how the use of technology has made it increasingly difficult to maintain individual privacy).

${ }^{173} \mathrm{See}$, for example, Weinreb, $42 \mathrm{U}$ Chi L Rev at 82 (cited in note 153) (discussing how around-the-clock video camera surveillance of Central Park in New York City might drive out lovers wishing to hold hands in private as well as muggers).

${ }^{174}$ See Steinberg, 74 Minn L Rev at 572 (cited in note 12) ("[The] requirement of publicity contrasts with the secret police operations of the stereotypical totalitarian state.... The public knowledge accompanying a traditional physical search helps prevent arbitrary government action.") (citations omitted). See also notes 153-56 and accompanying text. 
more easily watch its citizens while keeping its own activities secret.

Third, not only does sense-enhancing technology restrict the ability of individuals to secure privacy, it also chills the exercise of privacy-dependent rights by narrowing the individual's subjective expectation of privacy. ${ }^{175}$ Citizens will often not know how or when they are being watched, both because sense-enhanced surveillance can often be done secretly and because the form of observation constantly evolves. The fear of observation-not observation itself-may discourage an individual from exercising her rights. In this way, fear of sense-enhancing technology can chill the exercise of privacy-dependent rights to an extent even greater than the technology's actual capabilities. ${ }^{176}$

On the other side of the scale, advancements in the technology of surveillance provide benefits to society in the form of more effective law enforcement. ${ }^{177}$ As a result, our society's appetite for law enforcement may ultimately determine the level of Fourth Amendment protection that the individual citizen enjoys. ${ }^{178} \mathrm{Al}-$ though police use of sense-enhancing technology raises significant Fourth Amendment concerns, those concerns do not justify an outright ban on the warrantless use of such technology. Instead, lines must be drawn between permissible and impermissible uses of such technology.

\section{Fourth Amendment Values and Infrared Imaging}

Infrared imaging of a home infringes the values embodied in the Fourth Amendment to such a degree that it should be deemed a search within the meaning of the Fourth Amendment. Consequently, police use of infrared imaging on homes should be subject to the reasonableness requirement set forth in that amendment.

175 Steinberg, 74 Minn L Rev at 570-71 (cited in note 12).

136 George Orwell foresaw this possibility, writing: "There was of course no way of knowing whether you were being watched at any given moment . . . It was even conceivable that they watched everybody all the time.... You had to live-did live, from habit that became instinct-in the assumption that every sound you made was overheard, and ... every movement scrutinized." George Orwell, Nineteen Eighty-Four 158 (Clarendon 1984).

${ }_{177}$ See Katz, 65 Ind $L J$ at 550-51 (cited in note 156) (discussing law-enforcement benefits); Westin, 66 Colum $L$ Rev at 1046-47 (cited in note 164) (same).

${ }_{178}$ See Tomkovicz, 36 Hastings L J at 695-96 (cited in note 156) (rejecting idea that societal norms should decide the level of protection). 
The home has traditionally received a heightened level of protection under Fourth Amendment jurisprudence. ${ }^{179}$ For example, "[i]t is a 'basic principle of Fourth Amendment law' that searches ... inside a home without a warrant are presumptively unreasonable." ${ }^{180}$ Drawing on the language in the Fourth Amendment that specifically provides for the "[t]he right of the people to be secure in their... houses, ${ }^{\text {p181 }}$ the Supreme Court has concluded that this language "unequivocally establishes the proposition that "[a]t the very core [of the Fourth Amendment] stands the right of a man to retreat into his own home and there be free from unreasonable governmental intrusion."182 In addition, an individual's "zone of privacy" is most "clearly defined [ ] when bounded by the unambiguous physical dimensions of [his] home." ${ }^{\text {183 }}$ The zone of privacy found in the home arguably provides the most important forum for the exercise of privacy-dependent rights and serves the noninstrumental end of allowing individuals to find the comfort and contentment that comes with privacy in the home. ${ }^{184}$

Infrared imaging of homes infringes individual privacy and is, therefore, intrusive. Although infrared imaging cannot definitively reveal intimate details of life in the home, it nevertheless can provide the police with useful information that they would not otherwise be able to obtain. ${ }^{185}$ Like the canine sniff at the apartment door in Thomas, the infrared imaging of homes is "a way of detecting the contents of a private, enclosed space ... accomplished by a superior, sensory instrument" that likewise represents a privacy-infringing governmental intrusion. ${ }^{186}$

179 For example, in Thomas, the Second Circuit distinguished between warrantless canine sniffs of luggage brought to the airport and a warrantless canine sniff performed on the front door of a private residence, and held the latter to be unconstitutional. 757 F2d at 1366-67. Compare also United States v Karo, 468 US 705, 713 (1984) (Warrantless use of a beeper in a home is unconstitutional.), with United States $v$ Knotts, 460 US 276, 285 (1983) (Warrantless use of beeper to track a car is permissible.). For other cases discussing the importance of privacy in the home, see Soldal v Cook County, 506 US 56, $62-65$ (1992); Payton v New York, 445 US 573, 586 (1980).

180 Payton, 445 US at 586.

181 US Const, Amend IV.

182 Payton, 445 US at 589-90 (alteration in original), quoting Silverman $v$ United States, 35 US 505, 511 (1961). See also Oliver, 466 US at 178-79 (discussing the special protection for the home under the Fourth Amendment).

133 Payton, 445 US at 589.

184 See text accompanying notes 167-70.

185 See text accompanying notes 15-22.

${ }_{186} 757$ F2d at 1367. See also United States $v$ Taborda, 635 F2d 131, 139-40 (2d Cir 1980) (use of telescope to see objects in a home that would have otherwise been 
However, not all police practices that infringe Fourth Amendment values necessarily warrant Fourth Amendment protection. ${ }^{187}$ Instead, under the Katz approach, for Fourth Amendment protections to apply the individual must have a subjective expectation of privacy and the expectation of privacy must be objectively reasonable. ${ }^{188}$ Infrared imaging of homes satisfies both of these requirements and is thus a search within the meaning of the Fourth Amendment.

Courts have recognized the difficulty of applying the subjective expectation prong to infrared imaging because of the fact that heat inevitably dissipates. An individual can avoid infrared imaging only by not producing heat. ${ }^{189}$ Courts have understandably looked to other indicia to determine whether a person has exhibited a subjective expectation of privacy in heat production. For example, to avoid "render[ing] Katz' first prong meaningless," the court in Ishmael concluded that the defendants had exhibited a subjective expectation of privacy by "construct[ing] the [drug] laboratory in great secrecy," even though they ventilated excess heat using exhaust fans. ${ }^{190}$ The Cusumano panel agreed with the decision in Ishmael, concluding that "[t]o hold otherwise would leave the privacy of the home at the mercy of the government's ability to exploit technological advances: the government could always argue that an individual's failure (or inability) to ward off the incursions of the latest scientific innovation forfeits the protection of the Fourth Amendment..191

This approach makes sense. Because heat cannot be contained by any means, it makes little sense to require an individual to contain heat to defeat a claim of knowing exposure to the public. Furthermore, the purposeful ventilation of heat often represents the only effective means of concealing that heat from infrared imaging. Therefore, where an individual has taken mea-

unobservable is a search). But see United States $v$ Bonfiglio, 713 F2d 932, 937 (2d Cir 1983) ("[I]t was not the enhancement of the senses per se that was held unlawful in Taborda, but the warrantless invasion of the right to privacy in the home.").

187 See, for example, Smith, 442 US at 741-46 (holding that use of a pen register, a mechanical device that records the numbers dialed on a telephone, is not a search). See also text accompanying notes 177-78.

${ }_{188} 389$ US at 361 (Harlan concurring).

189 See Ishmael, 48 F3d at 854. See also text accompanying 76-77. Moreover, because the human body may give off heat sufficient for an infrared imaging device to detect, there is no viable means for an individual to prevent the production of all heat.

${ }_{190}$ See Ishmael, 48 F3d at 854. See also Katz, 65 Ind L J at 559-60 (cited in note 156) (noting how Katz "failed to offer much guidance for future cases").

${ }^{191}$ Cusumano, $67 \mathrm{~F} 3 \mathrm{~d}$ at 1503. 
sures to conceal his activity against more conventional means of investigation, the production of heat should not defeat an individual's claim to a subjective expectation of privacy. If a person could only substantiate a subjective expectation of privacy by producing average levels of heat, then the orchid grower and the hot tub enthusiast, as well as the marijuana grower, may face unwanted governmental intrusions, even if they otherwise secretly conducted each activity in their basements.

With respect to the second prong of Katz, society recognizes the right of an individual to be free from infrared imaging in his home. Unlike the facts in Place, in which the police openly seized a person's luggage in an airport and subjected it to a canine sniff, the infrared imaging of homes entails a surreptitious governmental incursion in a place traditionally afforded a heightened level of protection. ${ }^{192}$ Similarly, unlike Greenwood, in which the police inspected trash left at the curbside, the occupants of a house are not deliberately removing their heat in any meaningful way. ${ }^{193}$ Instead, infrared imaging entails the unobtrusive production of information about the interior of a home, thereby potentially revealing information the occupant would rather keep secret and did not deliberately expose to the police.

In Cusumano, the Tenth Circuit panel also reasoned "that the bug at issue in Katz was fixed to the outside of a public phone booth," and therefore "[r]educed to its operational fundamentals, that bug did not monitor the interior of the phone booth at all."194 Instead, "it measured the molecular vibrations of the glass that encompassed that interior" or "[a]lternatively, it might fairly be said that the bug passively recorded the propagation of waste vibrational energy into the public sphere." 195 These analogies to Katz powerfully suggest that infrared imaging, like the bug placed on the exterior of a phone booth, also undermines a reasonable expectation of privacy: infrared imaging collects infrared radiation emitted from the exterior of a home's walls in a

${ }^{192}$ See Cusumano, $67 \mathrm{~F} 3 \mathrm{~d}$ at $1509 \mathrm{n} 27$. ("We note, furthermore, that the luggage examined in Place, [462 US at 698-99,] far from being secreted in the basement of a home, had been voluntarily brought into a public place.").

${ }^{193}$ Cusumano, 67 F3d at 1508 (Greenwood "turned upon two factors: the voluntary nature of the relinquishment of trash into the hands of third parties and the frequency with which people or animals rummage through curbside garbage bags. ... It is neither common nor expected for homes to be scanned with thermal imagers, nor can the process by which heat signatures escape through the walls of the home be termed voluntary within the common usage of that word.") (citations omitted).

194 Id at 1501.

195 Id. 
manner analogous to the collection of sound waves by the bug used in Katz.

Furthermore, infrared imaging sufficiently infringes the values embodied in the Fourth Amendment to lead to the conclusion that society would recognize an individual's expectations of privacy as reasonable. First, the unobtrusiveness of infrared imaging limits the ability of an individual to protect his privacy by curtailing an activity when he knows or has reason to believe that the police might be watching. But more importantly, since heat cannot be contained, the individual simply cannot conceal heat-producing activities from police armed with an infrared imaging device. That the Fourth Amendment provides the only effective means of protecting the individual's reasonable expectation of privacy in this context only buttresses this analysis.

Second, the imager's ability to reveal at least some details almost certainly removes some degree of comfort and contentment that individuals have traditionally found in the home. Lastly, because the imager can reveal information about activities occurring within the home, individuals may be wary of exercising privacy-dependent rights in their own homes. Just as the Thomas court concluded that some measure of judicial oversight is necessary for canine sniffs on the exterior of a home, so too should infrared imaging receive some measure of regulation in that context. $^{196}$ It stands to reason that society would find an individual's expectation of privacy reasonable where she expected that she could conceal her approximate location in her own home by drawing her blinds. Society should not find it reasonable that the police could so easily undermine this expectation by using an infrared imaging device.

The intrusiveness of infrared imaging also becomes apparent when one examines the implications of holding that infrared imaging is not a search. The Fourth Amendment imposes no limitations on a criminal investigatory activity not considered to be a search, leaving the police largely free to target such activities at any individual for any reason or for no reason at all. ${ }^{197}$

196 See Thomas, $757 \mathrm{~F} 2 \mathrm{~d}$ at 1367 . The Thomas court required police to acquire a warrant by showing probable cause in order to use a canine sniff to detect the smell of narcotics emanating from underneath the front door of an apartment. Id. Although the canine sniff issue lies outside the scope of this Comment, applying the approach advocated here to the facts of Thomas would suggest that courts consider the sense-enhancing capabilities of drug-detecting dogs in light of the values embodied in the Fourth Amendment in order to determine what level of Fourth Amendment protection (if any) is required.

197 See Katz, 65 Ind L J at 551-55 (cited in note 156) (suggesting that searches should 
Therefore, if infrared imaging is not a search, the Fourth Amendment would not prevent the police from, for example, systematically or randomly imaging large numbers of homes. Such indiscriminate infrared imaging would be inconsistent with the Fourth Amendment's proscription of general searches and would substantially undermine the individual's ability to secure privacy in anonymity and seclusion. Moreover, such searches, if targeted at minorities, would disproportionately infringe the exercise of the privacy-dependent rights of those minorities and thereby unfairly tilt the political process against them.

Admittedly these harms are speculative, but if imaging is not a search, the police would not be accountable for its use. This lack of accountability along with the uncertainty it would create might chill the exercise of privacy-dependent rights by narrowing the sphere in which individuals perceived that they were free from governmental intrusions. The limitations imposed by the Fourth Amendment should therefore apply. ${ }^{198}$

be subcategorized into searches and "intrusions"). See also Fishman, 26 Am Crim L Rev at 349 (cited in note 171) (discussing how increasing capabilities of search equipment may increase what is knowingly exposed to the public and thus not protected by the Fourth Amendment). For a more thorough discussion of the shortcomings of the all-or-nothing approach, see Susan Moore, Note, Does Heat Emanate Beyond the Threshold?: Home Infrared Emissions, Remote Sensing, and the Fourth Amendment Threshold, 70 Chi Kent L Rev 803, 842-60 (1994).

198 While the primary aim of this Comment has been to argue that warrantless infrared imaging of homes intrudes on a reasonable expectation of privacy and should, therefore, be considered a search for purposes of the Fourth Amendment, a few comments on the question of what level of suspicion is required to justify such a search are warranted. Under current Fourth Amendment jurisprudence, if a particular criminal investigatory practice is a search, then prior to using that technique to search a house absent exigent circumstances, the police must demonstrate probable cause and obtain a warrant. See Wayne R. LaFave, 1 Search and Seizure: A Treatise on the Fourth Amendment $\S 2.1(\mathrm{e})$ at 315 (West 2d ed 1987); Amsterdam, 58 Minn L Rev at 374 (cited in note 8). However, a finding that infrared imaging intrudes on privacy interests protected by the Fourth Amendment should not necessarily require a court to apply this all-or-nothing approach. Specifically, Professor Katz has recently suggested that certain types of police activity currently considered searches within the meaning of the Fourth Amendment could be permissible upon a showing of reasonable suspicion rather than probable cause. Katz, 65 Ind $L J$ at 581-82 (cited in note 156). Analogizing to Terry $v$ Ohio, 392 US 1 (1968) Katz argues that the Court should recognize an intermediate category of searches, known as "intrusions," which would be justified by reasonable suspicion rather than probable cause, and places sense-enhancing technologies in this intermediate category. Katz, 65 Ind $\mathrm{L} J$ at 581-82. For further discussion of this idea, see LaFave, 1 Search and Seizure § 2.1(e) at 314-15. Although a thorough analysis of the level of suspicion courts should require for infrared imaging is beyond the scope of this Comment, Professor Katz's approach has much to commend it. In the context of infrared imaging, this less restrictive standard likely strikes a better balance between the values embodied in the Fourth Amendment and the ability of the police to enforce the laws. 


\section{CONCLUSION}

By considering the values embodied in the Fourth Amendment and the extent to which the use of infrared imaging undermines these values, the technological approach leads to the conclusion that the infrared imaging of a house is a search within the meaning of the Fourth Amendment. Perhaps more importantly, the technological approach provides a starting point for analyzing future developments in sense-enhancing technology. A thorough understanding of the sense-enhancing technology-both its capabilities and limitations-must be the starting point for any Fourth Amendment analysis. Only by considering the values embodied in the Fourth Amendment in light of the capabilities of the sense-enhancing technology employed will courts be able to determine whether new technologies sufficiently interfere with privacy interests as to constitute a search within the meaning of the Fourth Amendment. 